\title{
Role of Fair Reward, Incentives and Remuneration System for Motivating Sales People of Banking, Financial Services and Insurance (BFSI) Sector
}

\author{
Dr. Parihar Suresh Dahake
}

Assistant Professor, Department of Management Technology, Shri Ramdeobaba College of Engineering and Management, Nagpur

Email:dahakeps@rknec.edu

\author{
Received: $20^{\text {th }}$ September 2018, Accepted: $11^{\text {th }}$ October 2018, Published: $31^{\text {st }}$ October 2018
}

\begin{abstract}
Purpose: The paper intends to study the factors and essentials of fair incentive, rewards system which drives Banking and Finance salespeople to be productive, and also understand are they generate sales for business or not. Sales jobs, especially for financial products is extremely competitive for employees those who works as a salesman, A smart sales managers can use to his skills, ability, and knowledge for getting an advantage in increasing sales income and profit.

Methodology: The data was collected through an administered questionnaire in direction to get the first-hand information on perception. ANOVA method used to test the significance \& hypothesis testing. The research though covered people from different areas; the field of study was limited to Nagpur city only.

Practical Implications: Nagpur city has included in the first list of emerging smart cities; it is a fast growing city $\&$ holds significance in direction of growth potential of investment and banking in central India.

Findings: Encouragement by rewards and incentive system play key role to search new business opportunities for the growth of the company, and rewarding the salesperson and sales executive's people who do their best job of bringing new customers from the saturated market. It is also highlighted the viability of reward and incentive system to motivate sales people who work in a commission based environment and putting effort into their work for reaching their sales target and goal.

Originality: This paper presents the actual researched picture of Banking, Financial Services and Insurance (BFSI) Sector sales person's viewpoint in the Nagpur city. It shows that good and sound remuneration/compensation plan is one of the effort to meet with the expectation and aspiration of sales force on one hand, and overall objectives of management on the other. Keeping Salesforce, Sales team, motivated will be quite easier when business facing good time and selling of products are flowing freely in the market, but when business hits a rough patch it can be a herculean task to keep their top salespersons and performers on board.
\end{abstract}

Keywords

Incentive, Sales, Reward, Remuneration, Motivation, Salesman

\section{Introduction}

Motivation is the psychological set of forces influencing the behaviour of an individual. It involves a complex combination of individual needs, and motivation is having an ability to influence the sales-force in such a direction to get them to do what their performance and expect them to do. To motivate a sales force a sales manager expected to know the needs, emotions, aspirations, and expectations of his salesman's. Hence good remunerations and compensation plan is one of the strategy to fulfil the expectations and aspirations of the salesforce. Sales is implemented in all category and it includes the salespeople to be engaged in direct selling, personal or face-to-face selling and via telephone calling. An Account manager is accountable and responsible for a number of customers and staff providing for technical support such as sales people and sales-force. The diverse nature of sales means that compensation packages for sales staff vary greatly, with a number of organizational factors influencing both the type and level of rewards on offer. The products and services being sold, as well as the types of customers, will impact on how sales personnel are remunerated.

\section{Scope for this Study}

Organizations need employees who are committed, flexible, and ready to participate in decision making activity to take crucial decision. Retaining high performer and enthusiastic employees in the organizations is becoming essential and vital in today's competitive environment and for that commitment from employees side the organization has to compensate as per the need and effort of salesman. First and prior objective of remuneration plan is to keep work attractive and maintain top flight workforce. And this study helps to understand all those factors which is important to recognize the real needs of salesman regarding remuneration is concerns 


\section{Review of Literature}

(Rogers and Peccoud 2005) states that the Organizations that put the front line staff motivated and satisfied and fulfil them with the right tools are most likely to enjoy long term superior and excellent performance. (Milkovich, 1988) stated that " Sales employees playing a vital and key role in organizations, these people are the main public, and they are face of the organisation, with their primary responsibility for generating sales, profita and business. Hunter et al. (1990) stated that, the quality of the salesperson can make the difference between making a sale and marketing. Ross (1991) Gaba and Kalra (1999) these researchers found that that, when salespeople face the up-downs and discontinuation in a sales quota, the bonus plan specifically that salespeople can modify their sales selection strategies (high pay-off, high risk versus low pay-off and low risk) as a function of the current standing scenario to sales target.

\section{Objectives of Study}

1) To Study different methods to remunerating salesman to boost the sales of financial products.

2) To find the influence of remuneration on performance of sales person.

3) To know about requirements of sound remuneration plan and its contribution in rise in sales.

\section{Hypothesis}

1 Null Hypothesis:

H0.Sound remuneration has no significant impact on sales of financial products.

2 Alternate Hypothesis:

H1.Sound remuneration has a significant impact on sales of financial products.

\section{Research Methodology:}

This research is based analysis and evaluation and data collected by primary and secondary data in Nagpur City which have been collected through questionnaire, telephonic and online survey from various salesman's of BFSI Sector ( Decided 150 but actual tab in response 120), schedule questions and answers by sales personals , websites, magazines, journals, reference books on sales and marketing.

\section{Limitations:}

1) This study is limited only for Nagpur City.

2) The Period of this study is May-2018 to August-2018

\section{Methods to Remunerating Salesman:}

\section{1) Straight Salary or Fixed Salary Method}

It is oldest and simple and common method of remunerating salesman. Under this method fixed salary is paid to the sales-people or salesman irrespective of volume of the sales turned out by him. In which there is no extra income to do hard work and increasing ratio of sales. This method apply especially in FMCG and to sell Consumer durable goods.

\section{2) Straight Commission on Sales Method}

Under this method only commission is paid to the salesman on the volume of sales, thus sales less gets less commission and more sells get more commission but in this the compensation is based on effort put by salesman and commission can be progressive in terms of progress in efforts. This method apply specially in credit cards, and to sell banking products

\section{3) Combination of Salary and Commission Method or Salary Plus Commission Method}

Under this method remunerating salesman both salary and commission are paid to salesman i.e. straight salary and commission paid to the salesman. This is most popular method to remunerating the salesman. This method apply specially to sell electronics goods, agricultural products and medicines.

\section{4) Salary Plus Share in Profit only:}

Under this method the salesman is given some percentage in the profit besides the regular month salary. The share is given to overall profits of enterprises. This method apply specially in real estate sector and property dealing.

\section{5) Special Task Method:}

Under this method the sales man are assign special task to perform and the remuneration is also settled accordingly, as soon as task completed the salesman remunerated at prescribed rate. And his methods apply for road shows, trade shows, canopy, and direct marketing also.

\section{Requirements of Sound Remuneration Plan}

The Present study says that the remuneration plan has to be simple and it gives stability of income to the salesman which has to be guaranteed fair wages in attractive manner, it is timely n regular pay accordingly to them to keep their motivation in selling activity and improvising their effort in direction of profit maximization this faire charges of remuneration and reward is economical and fair to management and sales-force which creates a 
competitive environment in field of marketing and sales. Which has an effective control over it and playing a vital role for rise in sales in following way.

\section{Result and Discussion}

Analysis 1)

\begin{tabular}{|c|c|c|c|c|c|c|}
\hline \multicolumn{7}{|c|}{ Relationship of Financial Product Sold with Methods of Remuneration } \\
\hline \multicolumn{7}{|l|}{ Count } \\
\hline & & \multicolumn{4}{|c|}{ Methods of remuneration } & \multirow[b]{2}{*}{ Total } \\
\hline & & $\begin{array}{l}\text { Straight } \\
\text { salary or } \\
\text { fixed salary } \\
\text { method }\end{array}$ & $\begin{array}{c}\text { Straight } \\
\text { commissio } \\
\text { n on sales } \\
\text { method }\end{array}$ & $\begin{array}{c}\text { Combination of } \\
\text { salary and } \\
\text { commission method } \\
\text { or salary plus } \\
\text { commission method }\end{array}$ & $\begin{array}{c}\text { Salary Plus } \\
\text { share in Profit } \\
\text { only }\end{array}$ & \\
\hline \multirow{5}{*}{$\begin{array}{l}\text { Product } \\
\text { Sold }\end{array}$} & Mutual Funds & 9 & 11 & 1 & 2 & 23 \\
\hline & CA \& SA & 2 & 4 & 3 & 1 & 10 \\
\hline & $\begin{array}{c}\text { Long Term } \\
\text { Loans } \\
\end{array}$ & 1 & 7 & 1 & 1 & 10 \\
\hline & Insurance & 14 & 27 & 7 & 2 & 50 \\
\hline & SIP & 13 & 12 & 1 & 2 & 28 \\
\hline \multicolumn{2}{|r|}{ Total } & 39 & 61 & 13 & 8 & 121 \\
\hline
\end{tabular}

Table: 1 Relationship of Financial Product Sold with Methods of Remuneration (Source: Primary Survey Data)

\section{Relationship of Financial Product Sold with Methods of remuneration}

50

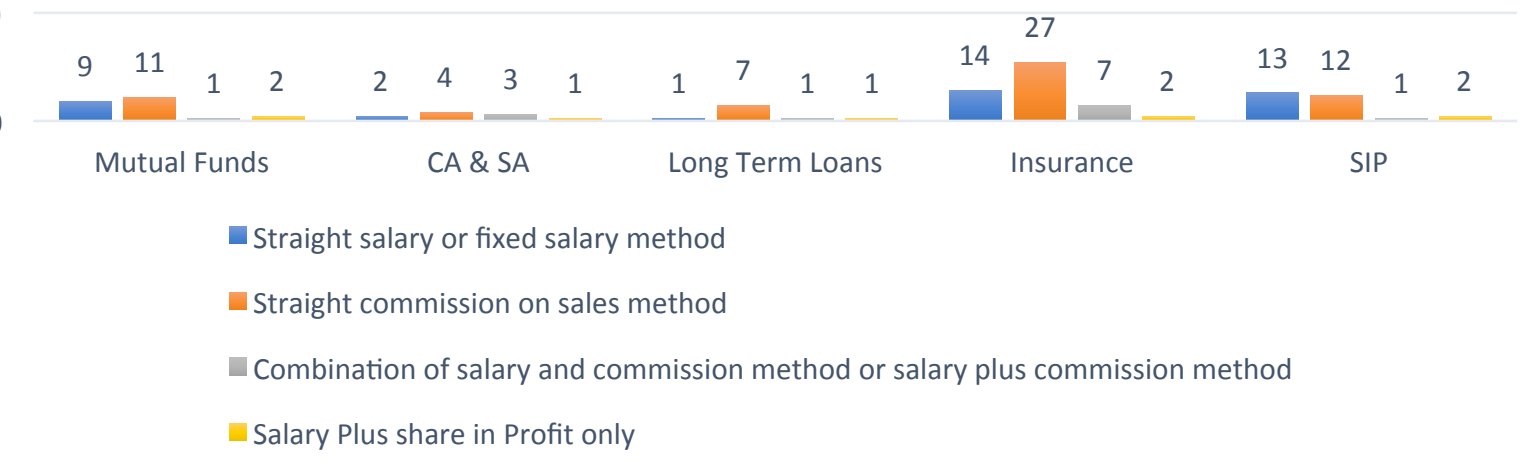

Graph 1: Relationship of Financial Product Sold with Methods of Remuneration (Source: Primary Survey Data)

In above table and graph 1, the Relationship of Financial Product Sold with Methods of remuneration is shown, in this analysis most of the Insurance agents influenced by remuneration system on other hand mutual funds SIP and mutual funds ranked on second and third spot respectively.

Analysis 2)

\begin{tabular}{|c|c|c|c|c|c|c|}
\hline \multicolumn{7}{|c|}{$\begin{array}{c}\text { Relationship of Financial Product Sold with Overall Satisfaction of Sales Person about Remuneration } \\
\text { System (Salesperson View) }\end{array}$} \\
\hline \multicolumn{7}{|l|}{ Count } \\
\hline & & \multicolumn{4}{|c|}{ Overall satisfaction about remuneration system } & \multirow{2}{*}{ Total } \\
\hline & & Very Satisfied & Satisfied & Neutral & Dissatisfied & \\
\hline \multirow{5}{*}{$\begin{array}{l}\text { Product } \\
\text { Sold }\end{array}$} & Mutual Funds & 6 & 14 & 2 & 1 & 23 \\
\hline & CA \& SA & 2 & 7 & 1 & 0 & 10 \\
\hline & Long Term Loans & 4 & 6 & 0 & 0 & 10 \\
\hline & Insurance & 12 & 29 & 6 & 3 & 50 \\
\hline & SIP & 8 & 18 & 1 & 1 & 28 \\
\hline \multicolumn{2}{|r|}{ Total } & 32 & 74 & 10 & 5 & 121 \\
\hline
\end{tabular}

Table 2: Relationship of Financial Product Sold with Overall satisfaction of Sales Person about Remuneration System (Salesperson View)

(Source: Primary Survey Data) 


\section{Relationship of Financial Product Sold with Overall satisfaction of sales person about remuneration system (Salesperson View)}

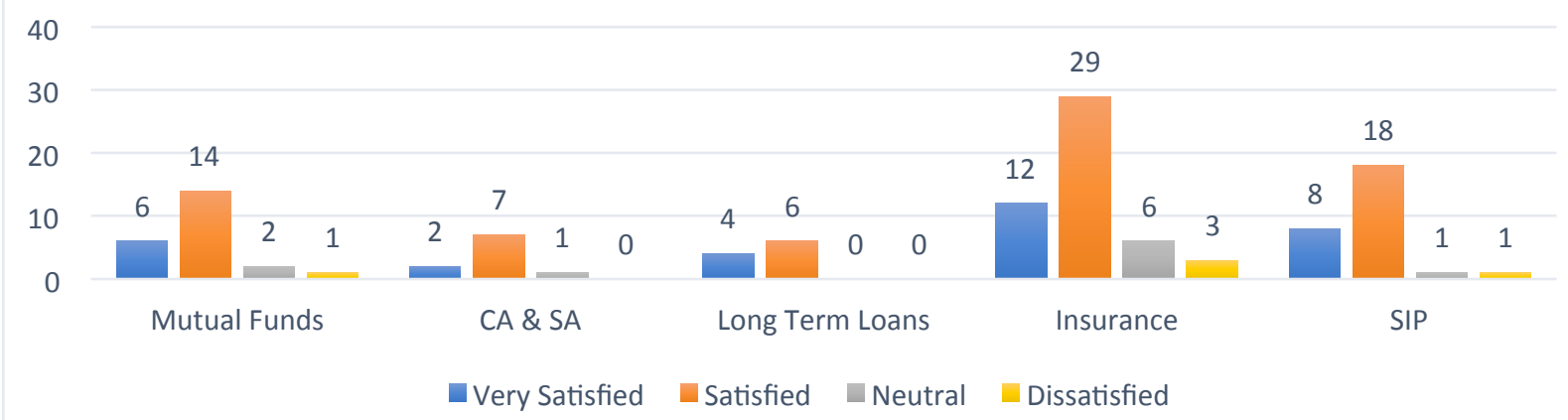

Graph 2: Relationship of Financial Product Sold with Overall satisfaction of Sales Person about Remuneration System (Salesperson View)

(Source: Primary Survey Data)

In above table and graph 2, the Relationship of Financial Product Sold with Overall satisfaction of sales person about remuneration system. In this analysis in all cases most of the employee were satisfied and highly satisfied with remuneration system and on other hand some of were neutral also. The ratio of dissatisfaction was very less.

Analysis 3)

\begin{tabular}{|c|c|c|c|c|c|c|c|}
\hline \multicolumn{8}{|c|}{$\begin{array}{c}\text { Relationship of Financial Product Sold with View about Role of Sound Remuneration System to Boost } \\
\text { Sales }\end{array}$} \\
\hline \multicolumn{8}{|c|}{ Count } \\
\hline & & \multicolumn{5}{|c|}{ View about remuneration system boost business } & \multirow[b]{2}{*}{ Total } \\
\hline & & $\begin{array}{l}\text { Strongly } \\
\text { Agree }\end{array}$ & Agree & Neutral & Disagree & $\begin{array}{l}\text { Strongly } \\
\text { Disagree }\end{array}$ & \\
\hline \multirow{5}{*}{$\begin{array}{l}\text { Product } \\
\text { Sold }\end{array}$} & Mutual Funds & 2 & 13 & 2 & 3 & 3 & 23 \\
\hline & CA \& SA & 2 & 4 & 2 & 1 & 1 & 10 \\
\hline & Long Term Loans & 3 & 5 & 1 & 1 & 0 & 10 \\
\hline & Insurance & 10 & 23 & 10 & 7 & 0 & 50 \\
\hline & SIP & 4 & 18 & 1 & 3 & 2 & 28 \\
\hline \multicolumn{2}{|r|}{ Total } & 21 & 63 & 16 & 15 & 6 & 121 \\
\hline
\end{tabular}

Table 3: Relationship of Financial Product Sold with View about Role of Sound Remuneration System to Boost Sales.

(Source: Primary Survey Data)

\section{Relationship of Financial Product Sold with View about role of sound remuneration system to boost sales.}

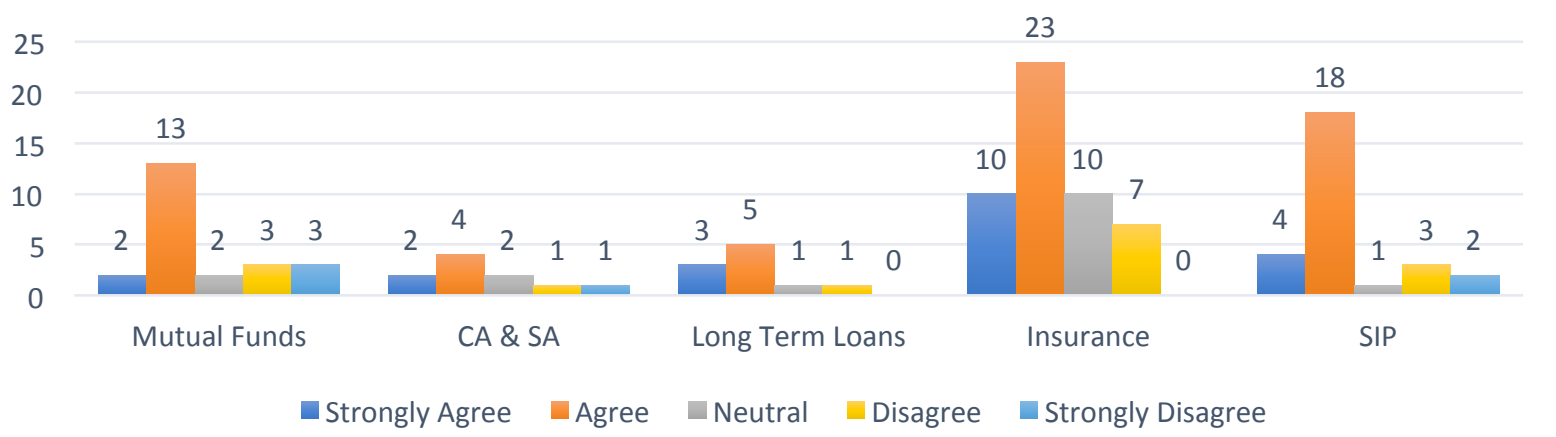

Graph 3: Table 3: Relationship of Financial Product Sold with View about Role of Sound Remuneration System to Boost Sales.

(Source: Primary Survey Data) 
In above table and graph 3, the Relationship of Financial Product Sold with View about role of sound remuneration system to boost sales. In this analysis in all cases most of the employee were agree with this, that the sound remuneration system play a vital role to boost the sales of financial products.

\section{Hypothesis Analysis and Interpretation}

\begin{tabular}{|c|c|c|c|c|c|}
\hline \multicolumn{7}{|c|}{ ONOVA } \\
\hline \multicolumn{7}{|c|}{ Overall Satisfaction about Remuneration System } & Mean Square & F & Sig. \\
\hline & Sum of Squares & df & Mean & .500 & .036 \\
\hline Between Groups & 2.566 & 4 & .641 & & \\
\hline Within Groups & 48.906 & 116 & 1.284 & & \\
\hline Total & 51.471 & 120 & & \\
\hline
\end{tabular}

\section{Interpretation}

Table 1: ANOVA Test Analysis

From the above one way Anova test researcher compare and analysed the View and satisfaction level of Sales people Sign values are $=\mathbf{0 . 0 3 6}$ Thus, the null hypothesis $\mathrm{HO}$ is rejected at $\mathbf{5 \%}$ level of significance and hence the alternate hypothesis is accepted. The alternate hypothesis is $\mathbf{H 1}$ i.e. Sound remuneration has a significant impact on sales of financial products.

\section{Suggestion}

- Companies can compensate your employees through non-monetary means These reward are from formal benefits and welfare (such as health, med claim and dental insurance)

- Organizations needs to be sure that they have mentioned and outlined clear expectations and goals for employees.

- Getting the right combination of base salary, variable pay and non-financial rewards.

- Listen to employees. Don't make any assumptions about what would be desirable or undesirable to them.

- Involve your employees before you design a plan. Gather information from a variety of sources about numerous programs.

- Install the plan, keeping in mind how it will be administered to provide for individual pay increases. You may want to use performance-based increases, promotions, increases for time spent with the company, or general increases to compensate for changing economic factors/cost of living and to remain competitive.

\section{Conclusion}

An effective remuneration and compensation plan will help to recruit, retain, and motivate employees. Establishing competitive pay scale and its range will help to attract efficient and high calibre employees appraising their performance and explaining its attachment towards pay, which will encourage his performance. Providing goals will keep employees interested in and enthusiastic about their present assignments. Sales force requires motivation as individuals and as a group members. As individuals they are target for personalized motivational efforts by theirs supervisors, selling financial products and services can be fraught with uncertainty and risks for both the organization and the sales representative. As a result, the most appropriate sales force compensation package is one that combines sufficient incentives to ensure staff are prepared to shoulder some of the risk with some level of guaranteed payment so staff do not feel all their efforts are wasted should a sale fail to materialize. A mix of benefits and perks can also be used to remunerate employees. By linking rewards to employee performance can increase employee motivation and achieve winning results.

\section{References}

1) Anderson E (1985)-The salesperson as outside agent or employee: a transaction cost analysis- Marketing Science

2) Anderson E \& Oliver R (1987) -Perspective on behavior-based versus outcome based sales force control systems- The Journal of Marketing

3) R.C. Agrawal- Salesmanship \& Advertising- Narains Publication revised edition-2007

4) Basu A., Lal R., Srinivasan V. and Staelin R (1985)-Sales force compensation plans- An agency theoretic perspective', Marketing Science

5) Brown D. \& Armstrong.(1999) Paying for contribution: the Real performance-related pay strategies- Kogan Page, London

6) Churchill G.,Ford N. \& Walker(1985)-Sales force management- planning, implementation and control, Richard D Irwin, Homewood, Illinois

7) Coughlan A. \& Narasimhan C. (1992) -An empirical analysis of sales force compensation plans', The Journal of Business. 
8) Donaldson B. (1998)-The importance of financial incentives in motivating industrial salespeople- The Journal of Selling and major Account Management 1:1, July.

9) Rees D. (2006) - Pay structures in CIPD reward management, loose-leaf-first published in 2005

10) Watson Wyatt Worldwide (2006) -Time management key to successful sales results- October 2006

11) Weilbaker D. (1999)-The Compensation issues for global account managers-The Journal of Selling and Major Account Management.

12) Book of C.L. Tyagi \& Mr. Arun Kumar - "Sales Management'

13) Steven M. Bragg, Essentials of Payroll- Management and Accounting (Hoboken, John Wiley and Sons, 2003), 21-22. 